\title{
Immunoglobulins in the mouse uterus during the oestrous cycle
}

\author{
Flore Rachman, V. Casimiri*, A. Psychoyos* and O. Bernard
}

Unité de Recherche d'Hépatologie Infantile, INSERM U 56, \& Clinique de Pédiatrie, Université Paris-Sud, Hôpital d'Enfants, and ${ }^{*}$ Laboratoire de Physiologie de la Reproduction, ER 203, CNRS, Hôpital de Bicêtre (Bât. INSERM), F-94270 Bicêtre, France

\begin{abstract}
Summary. The distribution of $\operatorname{IgA}, \operatorname{IgG}$ and $\operatorname{IgM}$ was studied by an immunoperoxidase technique on sections of mouse uteri at each stage of the oestrous cycle. Staining for IgG and IgA was highest at pro-oestrus, declined at oestrus and was very low during the other stages. At pro-oestrus IgG was found throughout the stroma, in the uterine lumen, and in $10 \%$ of glandular lumina; very few IgG-containing plasma cells were present. At pro-oestrus, $\operatorname{IgA}$ was found in the uterine lumen, and in most of the uterine glands, both in the lumen and in the epithelium; little $\operatorname{IgA}$ was present in the stroma. IgA-plasma cells were detected at each stage of the cycle and were particularly numerous at pro-oestrus and oestrus. These results suggest that $\operatorname{IgA}$ is secreted locally from plasma cells into the uterine gland through the glandular epithelium, but that IgG enters the stroma from the local capillaries. The obvious increase in IgG and $\operatorname{IgA}$ secretion at pro-oestrus, when plasma oestradiol levels are highest, supports the hypothesis that, during the oestrous cycle, the humoral immune response is regulated in the uterus by ovarian hormones.
\end{abstract}

\section{Introduction}

Several investigations have now established that the uterus forms part of a mucosal immune system which is common to the gut, bronchi, mammary gland and liver. Lymphocyte migration towards the mouse uterus and the presence of immunoglobulins in rat uterine fluid have been demonstrated and are probably hormone dependent (Wira \& Sandoe, 1977; McDermott, Clark \& Bienenstock, 1980; Wira, Hyde, Sandoe, Sullivan \& Spencer, 1980). Less is known, however, about the tissue distribution of immunoglobulins and immunoglobulin-containing cells in the uterus. The data obtained in humans are conflicting (Tourville, Ogra, Lippes \& Tomasi, 1970; Kelly \& Fox, 1979). IgA-plasma cells seem to be present throughout the oestrous cycle in rats (Wira et al., 1980).

Our previous observations suggest that during the preimplantation period of pregnancy in mice, the IgA produced locally by plasma cells is secreted into the uterine lumen via uterine glands, whereas IgG infiltrates the stroma but does not seem to be secreted locally (Bernard, Rachman \& Bennett, 1981). This report presents the results of studies of immunoglobulin distribution in the mouse uterus at the various stages of the oestrous cycle.

\section{Materials and Methods}

Six-week-old random-bred female mice of the OF1 strain were kept in cages containing 4 females each, next to cages containing male mice of the same strain, under a schedule of $14 \mathrm{~h} \mathrm{light}$ and $10 \mathrm{~h}$ 
darkness. These conditions were maintained for 2 weeks before the study. Mice whose vaginal smears showed regular oestrous cycles of 5 days were selected at a given stage of the cycle. They were killed by cervical dislocation and the vagina and uterine horns were removed. To confirm the stage in the oestrous cycle, the histology of the corresponding vaginal epithelium was studied after fixation in Bouin's alcoholic fluid, embedding in paraffin wax and staining with haematoxylin and eosin. Only mice in which the vaginal epithelial histology and vaginal smears were clearly characteristic of a particular stage of the cycle (Allen, 1922) were further examined for uterine immunoglobulins. Uterine horns were treated as previously described (Bernard, Ripoche \& Bennett, 1977; Bernard et al., 1981); briefly, each horn was ligated at both ends, fixed in 4\% paraformaldehyde and embedded in polyethylene glycol 1000;5 $\mu \mathrm{m}$ sagittal and transverse sections were incubated first with rabbit anti-mouse $\operatorname{IgA}$, IgG or IgM (Litton Bionetics, Kensington, Maryland), then with peroxidase-labelled sheep anti-rabbit immunoglobulin (adsorbed with mouse immunoglobulin) (Institut Pasteur Production, Dr M. Lavergne), and stained with diaminobenzidine and $\mathrm{H}_{2} \mathrm{O}_{2}$. Uterine horns from 3-5 mice were studied for each stage of the cycle.

Controls. The specificity of the various antisera and conjugates was checked as previously described (Bernard et al., 1981). Endogenous peroxidase activity was only present in eosinophils. These cells are known to be abundant in the endometrium at pro-oestrus and oestrus in the rat (Psychoyos, 1973) and were clearly distinguishable from cells staining specifically for immunoglobulins.

Quantitation of immunoglobulin-containing glands. To determine the proportion of glandular lumina containing IgA or IgG, all the glands visible in each sagittal section of the whole uterine horn were examined and the glandular lumina with and without IgA or IgG were counted separately. The number of glandular lumina in each section ranged from 36 to 322 (mean 104). Statistical analysis was performed using Student's $t$ test.

\section{Results}

\section{Distribution of immunoglobulins}

The distribution of plasma cells and immunoglobulins in the various parts of the uterus is shown in Table 1 and Pl. 1, Figs 1-6.

Table 1. Distribution of $\operatorname{IgG}, \operatorname{IgA}$ and $\operatorname{IgM}$ in the various structures of the mouse uterus at different stages of the oestrous cycle

\begin{tabular}{|c|c|c|c|c|c|c|c|c|c|c|c|c|}
\hline \multirow{2}{*}{$\begin{array}{c}\text { Stage of } \\
\text { oestrous cycle }\end{array}$} & \multicolumn{3}{|c|}{ Stroma } & \multicolumn{3}{|c|}{$\begin{array}{l}\text { Plasma cells } \\
\text { in stroma }\end{array}$} & \multicolumn{3}{|c|}{$\begin{array}{l}\text { Luminal } \\
\text { epithelium }\end{array}$} & \multicolumn{3}{|c|}{$\begin{array}{l}\text { Uterine } \\
\text { lumen }\end{array}$} \\
\hline & $\operatorname{Ig} A$ & IgG & IgM & $\operatorname{Ig} A$ & $\mathrm{IgG}$ & IgM & $\operatorname{IgA}$ & $\mathrm{IgG}$ & IgM & $\operatorname{Ig} A$ & $\mathrm{IgG}$ & IgM \\
\hline Dioestrus & - & Occas. & - & \pm & Occas. & - & - & - & - & \pm & Occas. & - \\
\hline Pro-oestrus & Rare & ++ & - & $+t$ & - & - & - & - & - & + & ++ & - \\
\hline Oestrus & - & + & - & ++ & $\begin{array}{l}\text { Very } \\
\text { rare }\end{array}$ & - & - & - & - & + & \pm & - \\
\hline Metoestrus I & - & \pm & - & + & Occas. & - & - & - & - & \pm & Rare & - \\
\hline Metoestrus II & - & Occas. & - & \pm & Occas. & - & - & - & - & Rare & Occas. & - \\
\hline
\end{tabular}

++ , strong staining; + , medium staining; \pm , faint staining; - , no staining; Occas., occasional.

Dioestrus. Very little immunoglobulin was detectable in the uterus except for a few IgAcontaining plasma cells in the stroma and some $\operatorname{IgA}$ visible in a few glandular and uterine lumina.

Pro-oestrus. The amount of immunoglobulins found in the uterus was highest at this stage of the cycle. IgG was present throughout the stroma (PI. 1, Fig. 5) but no IgG-containing plasma cells 

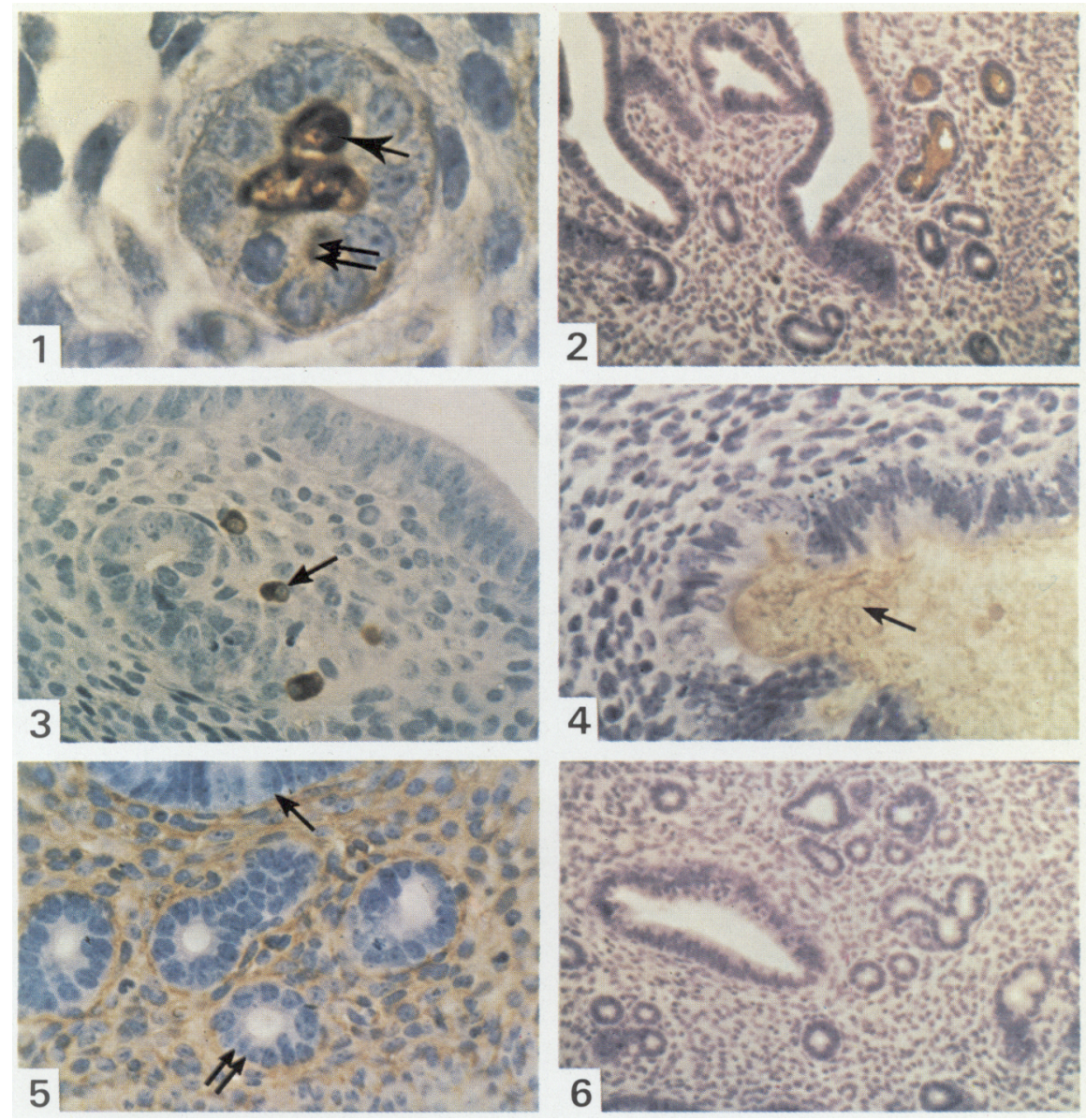

Immunoglobulins in the mouse endometrium during the oestrous cycle (indirect immunoperoxidase localization followed by haematoxylin staining).

Fig. 1. At pro-oestrus, IgA is present in the gland lumen (single arrow) and in epithelial cells (double arrow). $\times 633$.

Fig. 2. At pro-oestrus, about half of the glandular lumina contain IgA. $\times 100$.

Fig. 3. At dioestrus, some IgA-plasma cells (arrowed) are seen around empty glands. $\times 250$.

Fig. 4. At pro-oestrus, $\operatorname{IgA}$ is present in the uterine lumen (arrowed). $\times 250$.

Fig. 5. At pro-oestrus, $\operatorname{IgG}$ invades the stroma but is not seen crossing the uterine (single arrow) or glandular (double arrow) epithelium. $\times 250$.

Fig. 6. At pro-oestrus; there is no $\operatorname{IgM}$ visible in the plasma cells, glands or stroma. $\times 100$. 
were detected. The largest amount of IgG was observed in uteri from mice at the late pro-oestrous stage, as shown by vaginal epithelial histology, and staining was especially strong in the stroma next to the luminal epithelium. No IgG was visible in the glandular or luminal epithelia but it was clearly detectable in the uterine lumen and in a few glandular lumina. IgA-containing plasma cells were very conspicuous; most of these cells surrounded the glands. $\operatorname{IgA}$ was usually not detectable in the stroma, except occasionally as faint staining, but nearly half the glandular lumina (Pl. 1, Fig. 2) and a few cells in the glandular epithelium contained IgA (Pl. 1, Fig. 1). IgA was also present in the uterine lumen (PI. 1, Fig. 4), but not in the luminal epithelium. The number of IgA-plasma cells in the stroma seemed largest, and staining of $\operatorname{IgA}$ in the uterine lumen strongest, in the late prooestrous stage. IgM and IgM-containing plasma cells were never detected (P1. 1, Fig. 6), except in a few blood capillaries.

Oestrus. There was a general decrease in immunoglobulin levels, compared to pro-oestrus. Some staining of IgG was still present in the stroma and about one third of the glandular lumina contained IgA.

Metoestrus I. IgG was virtually undetectable, and IgA was less evident both in plasma cells and glands.

Metoestrus II. Staining for immunoglobulin was the faintest of all the stages of the oestrous cycle.

No IgG, IgA or IgM was visible in the epithelial cells of the uterine lumen at any stage of the cycle.

\section{Quantitation of immunoglobulin-containing glandular lumina}

During the oestrous cycle, the mean percentage of IgA-containing glands rose significantly from dioestrus to pro-oestrus $(P<0.01)$; at oestrus, it decreased slightly but not significantly and then significantly at metoestrus I $(P<0.05)$, thereafter declining further at metoestrus II (Text-fig. 1). The same trend was observed for IgG, although the percentage of IgG-containing glands was much lower.

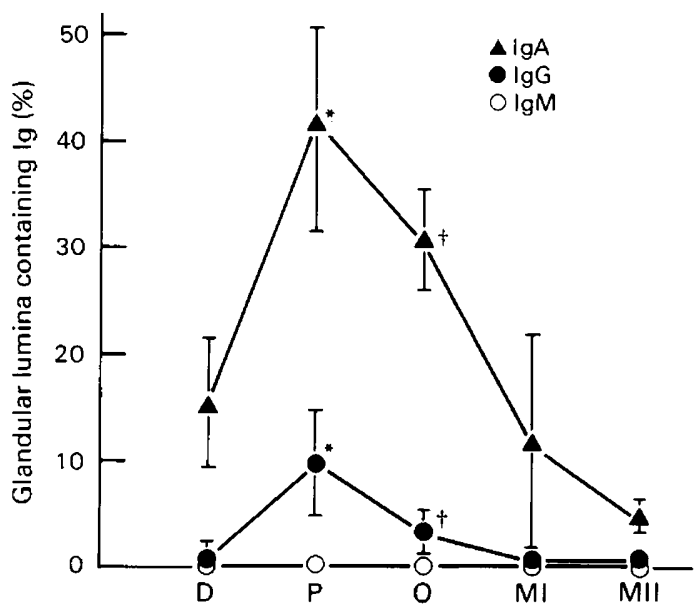

Text-fig. 1. The number of glandular lumina in mouse uteri containing $\operatorname{IgA}, \operatorname{IgG}$ or $\operatorname{IgM}$ at various stages of the oestrous cycle $(\mathrm{D}$, dioestrus; $\mathrm{P}$, pro-oestrus; $\mathrm{O}$, oestrus; $\mathrm{MI}$, metoestrus I; MII, metoestrus II). *Significantly different from value at dioestrus $(P<0.01$ for IgA; $P<$ 0.05 for IgG). †Significantly different from values at metoestrus I and II $(P<0.05)$. 


\section{Discussion}

These results show that, in mice, IgG and $\operatorname{IgA}$ are present in the endometrium and their distribution and amounts appear to vary with the stage of the oestrous cycle and the corresponding hormone fluctuations. These findings (1) further support the concept of hormonal regulation of $\operatorname{IgA}$ and $\mathrm{IgG}$ secretion in the rodent uterus, and (2) suggest that, during both the oestrous cycle and the first days of pregnancy, the mechanisms responsible for the presence of $\operatorname{IgA}$ and $\mathrm{IgG}$ are different. The regulation of uterine immunoglobulin secretion by ovarian hormones is suggested by several data; our results are consistent with those showing that IgA and IgG levels in the rat uterine fluid vary throughout the oestrous cycle, the highest levels being observed at pro-oestrus, when plasma oestradiol and progesterone concentrations are highest, and the lowest at dioestrus (Wira \& Sandoe, 1977, 1980). Also, oestradiol injection into ovariectomized rats induced accumulation of IgA and IgG into the uterine fluid (Wira \& Sandoe, 1977, 1980). It is therefore likely that the immunohistological changes affecting IgG and $\operatorname{IgA}$ observed here in mouse endometrium during the oestrous cycle are also hormone-dependent.

The mechanisms of immunoglobulin secretion in the uterus are probably different for each class of immunoglobulin. Our results for the mouse uterus show that IgM does not seem to be involved in local secretory immunity during the oestrous cycle, or in early pregnancy; the limited amount detected at the time of implantation was probably due to passive diffusion because of the major increase in vascular permeability at this stage (Psychoyos, 1960). Such increased permeability is probably responsible for the presence of $\mathrm{IgG}$ in the uterine stroma at pro-oestrus and oestrus (present study) and at the time of implantation (Bernard et al., 1981). Very few IgGcontaining plasma cells were visualized in the stroma during the oestrous cycle, and oestradiol is known to increase the blood flow as well as an oedematous tendency favouring the passive diffusion of macromolecules (Spaziani \& Szego, 1958). The mechanisms by which IgG reaches the uterine lumen at pro-oestrus remain unclear. As it was observed during the implantation period, despite the striking contrast between the IgG-filled stroma and the absence of luminal epithelial staining, some IgG may cross the glandular epithelium to reach the uterine lumen since it was detected in about $10 \%$ of glandular lumina at pro-oestrus. Alternatively, it might cross the luminal epithelium in a form not detectable by light microscopy (Parr, 1980). Previous data concerning IgA secretion in the rodent uterus have shown that, in mice, IgA-B lymphocytes migrate to the endometrium from the mesenteric lymph nodes, that this migration rate is highest at pro-oestrus (McDermott et al., 1980) and that, in ovariectomized rats, IgA lymphocytes also concentrate in the uterus after oestradiol injection but this effect is blocked by progesterone (Wira et al., 1980); it is also known that, in rats, the secretory component is detectable in the uterine fluid, mainly at pro-oestrus but also in ovariectomized animals after oestradiol injection as either free or IgA-linked secretory component (Sullivan \& Wira, 1981). Our results provide further information on the steps between lymphocyte migration and presence of $\operatorname{IgA}$ in the uterine fluid. They indicate that, in mice, IgA-plasma cells infiltrate the stroma during the oestrous cycle and the early stage of pregnancy (Bernard et al., 1981) mostly when oestradiol plasma levels are highest. These results also show that IgA is most probably transferred from the plasma cells into the glands, since it was detected in the cells of the glandular epithelium and in the lumina of about $40 \%$ of glands at pro-oestrus. This is consistent with the hypothesis that IgA binds to secretory component on the basal surface of the glandular epithelial cell, crossing the cell to be released in the gland lumen and then in the uterine lumen; the very faint staining for free IgA in the stroma at pro-oestrus may also reflect some IgA diffusion from the capillaries, as suggested previously (Bernard et al., 1981). Our results further indicate that IgA secretion in the uterine glands is continuous, because at each stage of the cycle plasma cells were detected, and $\operatorname{IgA}$ was visualized in the gland lumina and in a few glandular epithelial cells. As shown by the increased number of $\operatorname{IgA}$-containing glands at pro-oestrus, enhanced $\operatorname{IgA}$ secretion may result from an increase in the number of IgA-containing plasma cells at that time, leading to local release of $\operatorname{IgA}$ and an augmented transfer of secretory $\operatorname{IgA}$ through glandular epithelial cells. 
Whether secretory component synthesis is also enhanced in rodents at pro-oestrus under the influence of oestradiol has not yet been established but seems to be indicated by the findings of Sullivan \& Wira (1981).

We thank Mme M. Grelier and Mme R-M. Dreyfus for help with the preparation and revision of the manuscript. This work was supported by CNRS No. 03.3673 and UER Kremlin-Bicêtre No. 867.

\section{References}

Allen, E. (1922) The estrous cycle in the mouse. Am. $J$. Anat. 30, 297-371.

Bernard, O., Ripoche, M.A. \& Bennett, D. (1977) Distribution of maternal immunoglobulins in the mouse uterus and embryo in the days after implantation. J. exp. Med. 145, 58-75.

Bernard, O., Rachman, F. \& Bennett, D. (1981) Immunoglobulins in the mouse uterus before implantation. J. Reprod. Fert. 63, 237-240.

Kelly, J.K. \& Fox, H. (1979) The local immunological defence system of the human endometrium. $J$. Reprod. Immunol. 1, 39-45.

McDermott, M.R., Clark, D.A. \& Bienenstock, J. (1980) Evidence for a common mucosal immunologic system. II. Influence of the estrus cycle on B immunoblast migration into genital and intestinal tissues. J. Immunol. 124, 2536-2538.

Parr, M.B. (1980) Endocytosis in the uterine epithelium during early pregnancy. Prog. Reprod. Biol. 7, 81-91.

Psychoyos, A. (1960) Nouvelle contribution à l'étude de la nidation de l'oeuf chez la rate. C.r. hebd. Séance. Acad. Sci. Paris D 251, 3073-3075.

Psychoyos, A. (1973) Endocrine control of egg implantation. Handbook of Physiology: Endocrinology II, Vol. 2, pp. 187-215. Eds R. O. Greep \& E. V. Astwood. Am. Physiol. Soc., Washington D.C.
Spaziani, E. \& Szego, C.M. (1958) The influence of estradiol and cortisol on uterine histamine of the ovariectomized rat. Endocrinology 63, 669-678.

Sullivan, D.A. \& Wira, C.E. (1981) Estradiol regulation of secretory component in the female reproductive tract. J. Steroid Biochem. 15, 439-444.

Tourville, D.R., Ogra, S.S., Lippes, J. \& Tomasi, T.B. (1970) The human female reproductive tract: immunohistological localization of $\gamma \mathrm{A}, \gamma \mathrm{G}, \gamma \mathrm{M}$, secretory "piece" and lactoferrin. Am. J. Obstet. Gynec. 108, 1102-1108.

Wira, C.R. \& Sandoe, C.P. (1977) Sex steroid hormone regulation of $\mathrm{IgA}$ and $\mathrm{IgG}$ in rat uterine secretions. Nature, Lond. 268, 534-535.

Wira, C.R. \& Sandoe, C.P. (1980) Hormonal regulation of immunoglobulins: influence of estradiol on immunoglobulins $A$ and $G$ in the rat uterus. Endocrinology 106, 1020-1026.

Wira, C.R., Hyde, E., Sandoe, C.P., Sullivan, D. \& Spencer, S. (1980) Cellular aspects of the rat uterine $\mathrm{IgA}$ response to estradiol and progesterone. $J$. Steroid Biochem. 12, 451-459.

Received 10 November 1982 